\title{
Improving women's access to climate information services and enhancing their capability to manage climate risks
}

Rengalakshmi Raj a ${ }^{*}$, Devaraj $M^{\text {a }}$, Selvamukilan Bose a, Seenivasan Ramalingam a , and Britto Cas a

a M. S. Swaminathan Research Foundation, Chennai, 600 113, India

*Corresponding author.Email: rengalakshmi@mssrf.res.in

\section{ABSTRACT}

Climate information services has been demonstrated as a potential tool in supporting farmers to manage climate risks. However, the existing gap or disconnect between institutions that develop climate information and farmers who are the primary users of climate information can be addressed by building their capacity in an integrated manner by covering all the associated actors from production to use. This study primarily addressed the capacity building processes focussing on women's uptake of climate information at the users' level and value addition process of climate information into agro-advisories at the institutional level, to reduce the risk in agricultural production systems. The pathways for improving uptake and use of climate information to help decision-making by women farmers are: delivering information and agro-advisories relevant to their needs, having trained local level communicators, and group approach and support to act on the information. This paper demonstrates how capacity building of associated stakeholders in the whole climate information chain can address the barriers and improve the use and uptake of such information by women farmers, supporting their changing role in farming.

\section{INTRODUCTION}

\subsection{Context}

\subsubsection{Climate risks}

Climate variability and climate change are the most critical threats today in sustaining agricultural production, food safety, food quality and livelihoods of people depending on agriculture and retaining farmers' interest to take part actively in agriculture and make innovations (Howden et al., 2007; Gezie, 2019). In India, the most important climate change dimension relevant to farmers is increased frequency and severity of extreme events such as seasonal droughts, floods and cyclones (Food and Agriculture Organization of the United Nations [FAO], 2001; Mall, Singh, Gupta, Srinivasan, \& Rathore, 2006). Farmers in rainfed regions, especially smallholders, are highly vulnerable to these variations (Sathyan, Funk, Aenis, \& Breuer, 2018).

The intensity of climate change seems to be complex and has vast implications in agriculture and farmers' livelihoods. A study by

\section{KEYWORDS}

Adaptation, Capacity building, Climate change, Climate risk managers, India, Tamil Nadu, Women

\section{DOI}

https://doi.org/10.30852/sb.2020.946

\section{DATES}

Received: 12 September 2019

Published (online): 19 February 2020

Published (PDF): 16 March 2020

This work is licensed under a Creative Commons Attribution-NonCommercial 4.0 International License.

\section{HIGHLIGHTS}

» Trained women communicators enhance the uptake of climate information for women.

» Meeting women's climate information needs is the best pathway to enable information use.

" Group approach adds value to the demand for climate information.

»Collectives play a role in facilitating women's capabilities to act on climate information.

» Building capacities of associated stakeholders enables the use of climate information. 
the Ministry of Environment and Forest (MoEF), Government of India (GoI), has pointed out that extreme temperatures are anticipated to rise by $1^{\circ} \mathrm{C}$ to $4^{\circ} \mathrm{C}$ with a maximum rise in coastal regions; while extreme precipitation events will increase by 5 to 10 days in all four regions (The Himalayan, The Western Ghats, NorthEast and Coastal regions) with a decrease in frequency of cyclones and increase in their intensity by 2030 (MoEF, 2010). Another study by Kumar et al., 2011 over India showed that there would be an overall increase in temperature by $1^{\circ} \mathrm{C}$ to $4^{\circ} \mathrm{C}$ and summer monsoon precipitation by $9 \%$ to $16 \%$ by 2080 compared to the baseline 1970 , yet, on smaller regional scale some regions experience lower rainfall than the baseline period.

Such changes negatively impact the livelihoods of smallholders by affecting their production, income and employment. Based on the literature, the Economic Survey of India (2017-2018) study at the all India level reported that extreme temperatures and droughts have adverse impacts on farm incomes, especially in unirrigated agroecologies. It further stated that the year in which temperatures increase by one degree Celsius, farmer incomes would drop by $6.2 \%$ during the Kharif ${ }^{[1]}$ season and $6 \%$ during Rabi ${ }^{[2]}$ in unirrigated districts across India (GoI, 2018). Likewise, in a year when rainfall is $100 \mathrm{~mm}$ less than average, income would reduce by $15 \%$ during Kharif and by $7 \%$ during the Rabi season (GoI, 2018).

A study by International Labour Organization (ILO) warns that "the loss in productivity by 2030 because of heat stress could be the equivalent to India losing 34 million full-time jobs (up from 15 million in 1995), the highest among the world's most populous nations" (ILO, 2019, page 12). Also, there is some likelihood that the quality of the agricultural product (micronutrients-proteins) decreases under increased $\mathrm{CO}_{2}$ fertilization. Crops grown under elevated $\mathrm{CO}_{2}$ concentrations are more susceptible to insect pests. Weeds, insects and diseases are likely to increase in a warmer climate, and this will potentially reduce crop yields and lead to a decrease in agricultural productivity. Global warming may enhance bio-accumulation of fungal toxins (mycotoxins- aflatoxins, fusarium toxins) in crops like wheat and maize, posing a significant threat to food security. Achieving food security under a changing climate requires enhancing capacities of farmers to cope with the risks posed by climate change which can be achieved through climate change adaptation and mitigation measures (Kibria, Haroon, \& Nugegoda, 2013).

While in the state of Tamil Nadu, located in the southern part of the country, the impact of climate change is expected to be more in 2050 than in 2020 . The average yield reductions will range from $3.5 \%$ in paddy to $13.4 \%$ in sugarcane by 2020 and will be $4.5 \%$ and $9.4 \%$ in 2050 , respectively. In the Tamil Nadu State Action Plan for Climate Change, it is indicated "The PRECIS A1B scenario predicted that there is likely to be a decrease in rainfall in 2070 s by about $1 \%$ to $9 \%$ concerning the baseline rainfall (1970-2000). The maximum temperature is also likely to increase by about $3.1^{\circ} \mathrm{C}$ " (Government of Tamil Nadu [GoTN], 2015, page 98). Detailed analysis has shown that although there was no deviation in the annual rainfall and number of rainy days in Cauvery delta during the period 1970-2000, the river basins that fall south of the Cauvery river basin recorded a reduction in annual rainfall by $9.8 \%$ with a profound decrease in annual rainy days by $32.3 \%$ (Jain \& Kumar, 2012). Another study by Guhathakurta, Sreejith, and Menon (2011) between 1905 and 2005 shows that the number of dry days in the state has exceeded wet days in a year.

The main climate risks in Tamil Nadu affecting agriculture are increasing the occurrence of extreme events, mainly seasonal drought in consecutive years, which reduce the farmers' adaptive capacity and negatively impact their livelihood. Further, intra-seasonal distribution of rainfall, quantity and number of days, play an important role in agricultural production. Another vital aspect is cyclone impacts, which affect the production systems to a larger extent by damaging assets and infrastructure (GoTN, 2015).

\subsubsection{Changing role of women in agriculture}

These impacts of climate change and environmental shocks are particularly significant given the changing nature of women's engagement in agriculture. Women are more vulnerable to adverse climate impacts due to their marginalization, inequality, poverty and limited access to productive resources like knowledge, information, technology and institutional linkages (Carr \& Thompson, 2014). Women in the least developed countries and developing countries in Asia and Africa are responsible for food production (agriculture, livestock, fisheries, aquaculture), the collection of water and biofuel (wood), management of natural resources and taking care of children and elderly. Women farmer accounts for $45-80 \%$ of all food production in poor developing countries (UN Women Watch, 2009). Climate change is projected to cause a severe impact on rural women via crop failure, food and water contamination, shortages of biofuel and clean water, diseases and natural disasters, etc. (Kibria, 2016). The Economic Survey of India (2017-2018) cites the increasing trend of feminization of agriculture sector with the increasing role of women as cultivators, labourers and entrepreneurs (GoI, 2018). The changing trend is mainly due to growing rural-urban migration by men, an increase of 
women-headed households and an increase in the production of commercial crops which are labour intensive (FAO, 2019). Also, men are moving out to non-farm livelihoods, and as a result, women are increasingly involved in newer roles in agriculture, decision making and overall farm management. However, they have limited access to productive resources, including social and information and communication networks as compared to their men counterparts.

\subsubsection{Climate information services}

The climate information and advisory services are one of the potential ways to support farmers' to adapt to climate change (Carr, Goble, Rosko, Vaughan, \& Hansen, 2017; Tall, Coulibaly, \& Diop, 2018; and Singh et al., 2018). The improvements in climate forecast modelling have increased the accuracy of the forecast information at different spatial and temporal scales. Evidence has shown the positive results of forecasts in agricultural production by reducing risks in crop cultivation and allied sectors (Patt, Suarez, \& Gwata, 2005; Meinke et al., 2006). In India, currently, the Indian Meteorological Department (IMD) provides operational level Medium Range Weather Forecast (MRF) and Extended Range Forecast (ERF) at district and state spatial scale respectively. Based on the forecast, agro-advisories are developed by identified nodal organizations (Agro Meteorological Field Units) and disseminated to the farmers through several extension methods. In addition, IMD has recently initiated block-level MRF (reducing the spatial scale with increased efficiency) and advisories and district level ERF.

However, smallholders, especially women farmers, do not have timely access to climate information and capacity to translate forecasts into suitable crop advisories. Also, while developing the agro-advisories, gender-differentiated needs are not considered by the nodal organizations, and thus advisories are generally based on the major crops cultivated in the district, which is mainly food and commercial crops. Recently the World Meteorological Organization (WMO) initiated a discussion and reiterated the need for addressing the gender dimension in climate services concerning agriculture and food security, water management, etc. It also recommended increasing investment in climate services (production, dissemination and capacity building to use) to reduce the gender gap (WMO, 2015).

\subsection{Research questions}

Against this backdrop, the paper deals with the process undertaken to engender climate information services and facilitating its access and utilization by smallholder women farmers. An action research study

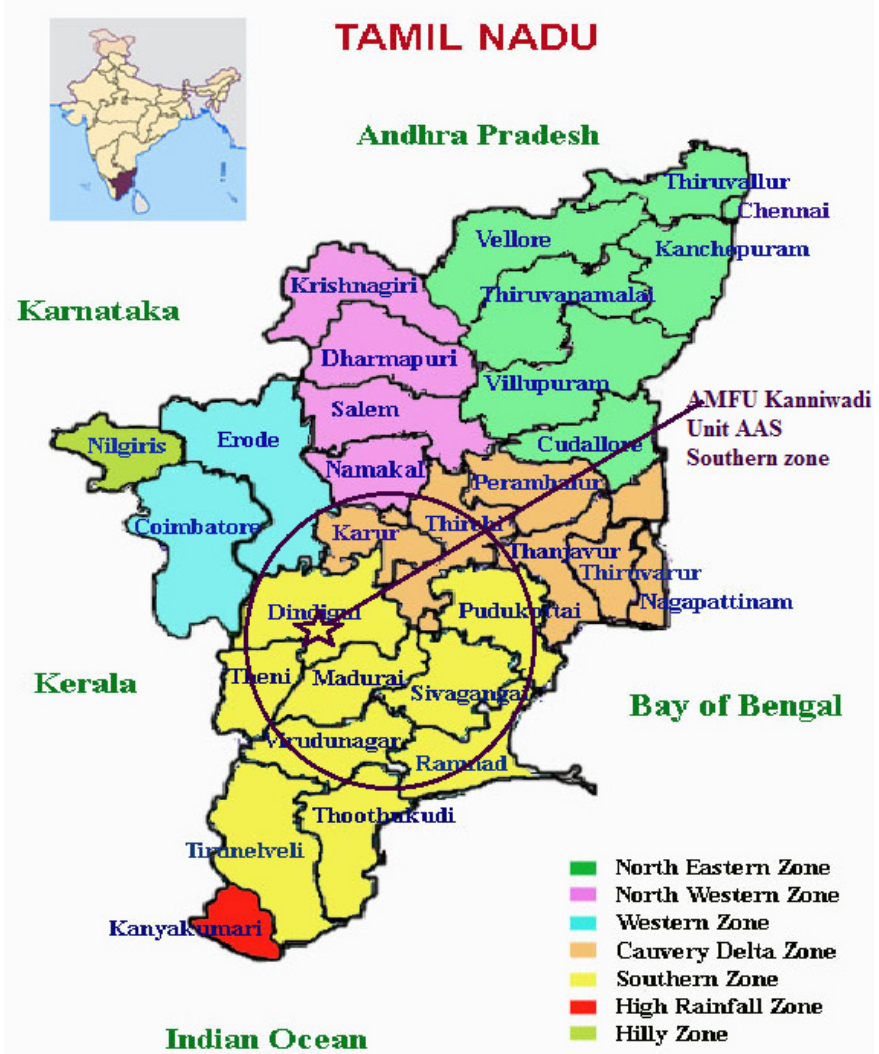

FIGURE 1. Agro-ecological zone in Tamil Nadu.

was undertaken from 2018-2019 in Tamil Nadu, India, to explore two research questions: (1) How to build the scientific capacity and leadership of women farmers in the uptake of climate information? Moreover, how can it be sustained at the community level? (2) How can the use of climate information to women farmers be enhanced?

\section{METHODOLOGY}

The study took place in the south zone of the Tamil Nadu, which is one of the seven agro-ecological zones in Tamil Nadu state (Figure 1) and consists of six districts (sub-unit). The zone has seven Agro Meteorological Field Units (AFMUs). The AMFUs is the nodal point at the zone level, and they receive weather forecasts and develop and disseminate agro-advisories.

Capacity development activities targeted four different sets of stakeholders who play a critical role in ensuring the appropriate climate information reaches farmers (Figure 2). The stakeholders were categorized into two levels: organizational level and grassroots level; at the organizational level, the first two sets of stakeholders (2.1 and 2.2) were involved, and the remaining two (2.3 and 2.4) were at the grassroots level. The number of members trained is given in Table 1.

The approach adopted in this intervention was in line with suggestion of Ambani and Percy (2014) in Africa, in which they have reiterated the need for capacity building of all stakeholders involved in the process of climate 


\begin{tabular}{|l|l|l|l|l|}
\hline $\begin{array}{l}\text { Category of the } \\
\text { programme }\end{array}$ & $\begin{array}{l}\text { Level of } \\
\text { interaction }\end{array}$ & $\begin{array}{l}\text { Type of stakeholders in the } \\
\text { climate/weather information } \\
\text { chain }\end{array}$ & $\begin{array}{l}\text { Total number of } \\
\text { participants }\end{array}$ & Main purpose of the programme \\
\hline $\begin{array}{l}\text { Organizational } \\
\text { level }\end{array}$ & State & $\begin{array}{l}\text { Agromet Field Unit (AMFU) } \\
\text { facilitators }\end{array}$ & 7 (7 M / o F) & $\begin{array}{l}\text { Adopting a gendered approach in } \\
\text { advisory development }\end{array}$ \\
\cline { 2 - 5 } & $\begin{array}{l}\text { South Zone } \\
\text { of Tamil } \\
\text { Nadu }\end{array}$ & $\begin{array}{l}\text { Farmers association [3] (FPO/ } \\
\text { federations/interest groups) }\end{array}$ & 21 & $\begin{array}{l}\text { Raising awareness and linkages to } \\
\text { facilitate climate information services } \\
\text { to farmers }\end{array}$ \\
\cline { 3 - 5 } & Climate Risk Managers (CRM) & 30 Female & $\begin{array}{l}\text { Building knowledge and skills on } \\
\text { climate risks and adaptation measures } \\
\text { especially climate information services }\end{array}$ \\
\hline Grassroots level & \multirow{2}{*}{ State } & Farmers & $\begin{array}{l}\text { Awareness to access and use weather/ } \\
\text { climate information }\end{array}$ \\
\cline { 3 - 5 } & & $\begin{array}{l}\text { Academicians, civil society } \\
\text { leaders, policymakers and } \\
\text { researchers }\end{array}$ & 14 (8 M/6 F) & $\begin{array}{l}\text { Sharing field evidence, results and } \\
\text { opportunities }\end{array}$ \\
\hline
\end{tabular}

TABLE 1. Details of participation in capacity building programmes. Note: The further information relating to farmers association and CRMs are included in annexures 1 and 2, respectively, in the supplementary material.

information at production, communication and adoption to realize its potential use in risk reduction.

The general objective of the initiative is to build the awareness, knowledge and skills, which varies among different stakeholders as outlined in Table 1. A series of workshops and a consultation were organized with various stakeholders as elaborated in Table 1. Before the initial workshops, a baseline assessment was done with all stakeholder categories to capture their level of knowledge, issues and use, respectively. At the end of the programmes, the assessment was repeated to understand the level of changes in their capacity to carry forward the weather/climate information services in a concerted manner in reaching women farmers.

At the AMFU facilitator level, the main focus was gender sensitization, while in the FPO/group level it was on awareness building on the use of climate information as well as to establish linkages with institutions to receive the climate information and advisories. At the next level with climate risk managers (CRMs), importance was given to build the knowledge and skills on climate risks and adaptation measures as well as communication with farmers and at the farmers level, it was on where to receive and use it for risk management. Finally, a consultation was held with relevant officials and researchers to share the learnings and results of the whole process.

\subsection{Training the facilitators of Agro Meteorological Field Unit}

At the first level, the facilitators of the AFMUs, who act as nodal points to receive the forecast and develop agro-advisories, were oriented on gender issues and preparing agro-advisories taking into consideration the differential needs of the diverse farmer's group in the field level. Participatory tools and processes were adopted to sensitize the facilitators on gender issues and to follow a gendered approach when preparing advisories. For example, when selecting crops/livestock for providing advisories, priority needs to be given to those crops in which women have a lead role, such as millet crops and floriculture, agronomic practices like weeding and harvesting which are typically assigned to women in the division of labour on different tasks and small ruminants and poultry which are primarily managed by women at the farm household.

\subsection{Training members of Farmer's Association (a network of small farmers)}

Twenty-one farmers' associations were identified for training. The main selection criteria were field presence of more than five years and between 500 to 1,000 members. The selected Farmer Producer Organizations (FPOs) were oriented on project objectives, activities, methods, expected outcomes and expected policy inputs. Following this, a consultative discussion was organized with selected farmer groups and the potential of climate information and agro-advisories in strengthening farmers' resilience, role of farmers' groups in the whole process and identifying innovative women farmers at the field level who could mediate the process of knowledge transfer at the local level to farmers, were explained.

\subsection{Building capacity of climate risk managers}

With the support of the farmers' associations, thirty community level intermediaries (women) were selected from 30 villages and trained to be CRMs to extend climate information services to local farmers regularly. The selection parameters for the CRMs were: 
lead farmers in adopting new technologies, innovators in refining technology to suit the local context, readiness to share the experiences and process with other farmers, already playing the role of leader in such processes, have minimum basic education and good mobilization and organization skills to discuss issues closely with farmers.

A simple training module was developed to train the CRMs on different aspects related to climate and weather forecasts, agro-advisories, institutions providing forecast and advisory details and contact details to access the information such as emails and phone numbers, assessment and understanding of local cropping systems/patterns, local agro-climatology, specialised training to understand the traditional knowledge about climate predictions from men and women farmers to initiate the dialogue and communicate with them, and potential adaptation practices using the climate information, etc. Then, seven training modules were developed to build the knowledge, skills and ability of CRMs to communicate climate information. The module covered the themes namely:

» weather and climate;

" what is climate change and factors triggering the change;

» impacts of climate change;

" addressing the challenges - both adaptation and mitigation methods;

» what is climate information;

» types of climate information;

" who is generating the forecast and advisory development; and

» simple thumb rules for adding value to weather information as advisories and communication of the information to the farmers.

Four capacity building programmes were organized face-to-face. The first meeting was arranged with all the CRMs gathered together, and the remaining three were conducted in their respective locations.

\subsection{Raising awareness and training women farmers on using climate information}

Each of the CRMs facilitated village level training of 100 women farmers in their respective locations by participating in farmer group meetings and screening videos to motivate discussion amongst them. The process of interaction was participatory and structured to get feedback from farmers on their traditional prediction and coping measures. Three thousand women farmers were trained using climate information through this approach. Also, efforts were taken to provide the agro-advisories through text SMS/voice SMS. In this process, 3,000 women farmers from 30 villages were trained and are receiving regular weather advisories.

\subsection{Policy advocacy interactions}

Policy level interaction was organized with the support of climate centre of Anna University in Chennai, and a roundtable discussion was conducted with officials from the Department of Environment and Forests, Government of Tamil Nadu, the nodal point for the development and implementation of the State Action Plan on Climate Change. The field-level experiences were presented in the meeting and discussed. As part of the dissemination process, a policy brief was prepared and shared with them. Discussions are ongoing to incorporate the recommendations in the state action plan on climate change. Also, there is scope to share the climate information services in the UNFCCC dialogues and discourses with the support of eminent researchers and officials engaged in policy-making processes.

\section{RESULTS AND DISCUSSION}

\subsection{Relevance of building the capacity of different actors in the climate information chain}

The capacity building initiatives adopted a whole chain approach in creating access and promoting utilization of climate information and suitable adaptation practices in the respective locations. As discussed, four different sets of actors were oriented on gender-sensitive climate information services (Table 1). Also, 3,000 women farmers are now linked with AMFUs to receive climate information and agro-advisories, continuously. Such knitted training and a comprehensive intervention at multiple levels help to increase the uptake of climate information. It was observed that in the initial phase, the women were not taking any decisions; they shared details with their family members. Before the training programme, though women had observed the changes in the weather pattern, they were not confident enough to comprehend and articulate their understanding. Their confidence increased following training, which is in line with evidence that a lack of awareness and capacity to access and use climate information is the main reason for the slow uptake in decision-making (Opitz-stapleton, 2010).

\subsection{Making relevance for climate information}

The experience shows that providing simple needsbased climate information improved the uptake by women farmers. Here, focus was given to build the capacity of the AMFU facilitators to (i) add value to their climate and weather forecasts that have relevance to women's actual needs; (ii) develop simple contents on 
how to address the issues with the sources to get more details and technical support, (iii) study the traditional knowledge in prediction and farmers practice in referring the intensity of the weather variables to enable the communication process; (iv) disseminate through women's groups and FPOs to reach more women farmers; and (v) use innovative communication modes like voice mails and social-based media such as WhatsApp audio messages to reach women with limited literacy skills.

The WMO has been advocating the need to provide clear and user-targeted information on weather and climate through its national focal points. In addition, it gives importance to improve the awareness of farmers and other user groups on the value of climate information in decision-making (WMO, 2007). A study by Kniveton et al. (2015) in Kenya and Senegal also clearly indicated the importance of producing user need-based information and advisories for practice.

\subsection{Profile and role of trained women communicators and group approach to improving the uptake of climate information for women}

Creating a cadre of intermediaries at the community level helps to improve the nodal points in the social network in seeking climate information. While identifying CRMs, care was taken to select CRMs who (i) lead in adopting new technologies, (ii) have a quest for and positive attitude towards continuous learning (iii) are willing to share experiences and processes with other farmers, (v) already play the role of leader in such processes, (vi) have basic education and can read and write; and (vii) have good mobilization and organization skills to discuss issues closely with farmers. The intensive and series of the capacity building programmes prepared the CRMs to communicate the climate information to the farmers effectively. It was evident from the pre- and post-capacity building assessments that their technical knowledge, skills, leadership capabilities, institutional linkages and social networks were improved.

Thus, using simple rules of thumb and understanding crop-weather relations, the CRMs were better equipped to develop and disseminate local and needsbased agro-advisories for weather and climate forecasts. Despite the increased awareness, women farmers' uptake of climate information is limited; however, the group approach helps to remove the barrier and enables women to share and demand climate information. In the farmer group meetings, participants shared their experiences in listing advisories, agronomic practices adopted in their field and changes, difficulty in understanding advisories, and additional information provided by FPO facilitators and others. Such discussions helped them to learn from each other and develop trust in the information. This is in line with findings from the recent research of Rengalakshmi, Manjula, and Devaraj (2018) in the study area that highlighted the results of women communicators in enhancing the use of climate information and its dissemination among women.

\subsection{Sustaining the demand for climate information}

Creating awareness among women on the availability of climate information services, supporting them in getting connected to services through a mobile network, strengthening their capacity to seek information and facilitating information-sharing mechanism in groups are some of the potential strategies to equip them to act on the information. The continuous interaction of CRMs with women in sharing the forecast and agro-advisories support women farmers to observe, develop trust and translate them the information into action. The CRMs are from the local village, and bi-weekly they share the weather forecast-based advisories suitable to the local farming system. Apart from this, they act as a link to avail other services of the FPOs. The CRMs deliver the agro-advisories by bundling with other services. For example, if the forecast advisory is for sowing maize/ cotton, then they provide information about the availability of quality seeds, its price and potential yield and performance. This bundling approach supports women farmers to come forward and use climate information services. However, limited resource control and lack of opportunity to participate in agricultural decision-making can significantly restrict women's capacity to make full use of climate information. Integration of these climate services along with other agricultural services like access to quality seeds of required crops and varieties, capacity building on technologies and institutional linkages can facilitate higher uptake of the information (Muema, Mburu, Coulibaly, \& Mutune, 2018).

\section{CONCLUSION}

Capacity-building programmes at multiple levels in the whole information chain seem to be a potential strategy in tackling gender-based issues that impact differing access to climate information to smallholders, especially women farmers whose role and direct contribution in agriculture is growing. In spite of the extension network to disseminate the climate information services, establishing a grassroots level cadre of women communicators is a best-practice strategy in improving the uptake of climate information as an adaptation measure. The new knowledge and learning on climate information and advisories paved the way for women farmers to understand the science behind actions and will enable 
them to take knowledge-based decision making for better farming in the context of increasing climate variability and change and lead to climate-smart agriculture. Sharing and showcasing the chain approach in capacity building with policymakers supported the provision of evidence and scientific input to policy decision-making processes, and was another positive outcome. The study attempted to ensure the sustainability of the initiatives through working with institutions at the state and grassroots level to improve the use and uptake of climate information in reducing climate risks.

\section{ACKNOWLEDGEMENT}

The authors acknowledge the financial support extended by the Asia-Pacific Network for Global Change Research (APN) to carry out the project.

The study team members sincerely thank Prof. M. S. Swaminathan, Founder Chairman, and Executive Director, MSSRF, Chennai for continuous guidance, motivation and encouragement. The team extends our gratitude for the cooperation and support provided by the Tamil Nadu Agricultural University, Indian Meteorological Department, Department of Agriculture, Tamil Nadu. Most importantly, the team thank the cooperation extended by the Farmer Producer Organizations, community resource persons and women farmers for their participation and inputs in making the study more enjoyable.

\section{REFERENCES}

Ambani, M., \& Percy, F. (2014). Facing uncertainty: The value of climate information for adaptation, risk reduction and resilience in Africa. CARE International. Retrieved from https://careclimatechange.org/ wp-content/uploads/2019/06/C_Comms_Brief.pdf

Carr, E., Goble, R., Rosko, H. M., Vaughan, C., \& Hansen, J. (2017). Identifying climate information services users and their needs in sub-Saharan Africa: A learning agenda. A Learning Agenda on Climate Information Services in sub-Saharan Africa, 38 pages.

Carr, E. R., \& Thompson, M. C. (2014). Gender and climate change adaptation in agrarian settings. Geography Compass, 8(3), 182-197. doi: 10.1111/gec3.12121

Food and Agriculture Organization of the United Nations. (2001). Reducing agricultural vulnerabilities to storm related disasters. Retrieved from http://www.fao. org/3/X9178e/X9178e.htm

Food and Agriculture Organization of the United Nations. (2019). FAO in India. Retrieved from http://www.fao. org/india/fao-in-india/india-at-a-glance/en/

Government of India. (2018). Climate, climate change and agriculture. In Economic Survey of India (2017-2018). (pp. 82-96).

Government of Tamil Nadu. (2015). Observed climate and climate change projections. In Tamil Nadu State Action Plan on Climate Change. Retrieved from https:// www.forests.tn.gov.in/tnforest/app/webroot/img/ document/Tamilnadu-Publications/2.pdf

Guhathakurta, P., Sreejith, O. P., \& Menon, P. A. (2011). Impact of climate change on extreme rainfall events and flood risk in India. Journal of Earth System Science, $120(3), 359$.

Howden, S.M., Soussana, J.F., Tubiello, F.N., Chhetri, N., Dunlop, M., \& Meinke, H. (2007). Adapting agriculture to climate change. Proceedings of the National Academy of Sciences, 104 (2007), 19691-19696, doi: 10.1073/pnas.0701890104

International Labour Organization. (2019). Working on a warmer planet: The impact of heat stress on labour productivity and decent work. Retrieved from https://www.ilo.org/wcmsp5/groups/public/dgreports/-dcomm/-publ/documents/publication/wcms_711919.pdf

Jain, S. K., \& Kumar, V. (2012). Trend analysis of rainfall and temperature data for India. Current Science (Bangalore), 102(1), 37-49.

Kibria, G., Haroon A.K.Y., \& Nugegoda, D. (2013). Climate change and agricultural food production: Impact, vulnerabilities and remedies. New Delhi: NIPA. doi: 10.13140/2.1.3245.4081

Kibria, G. (2016). Why Are Women in Developing Countries More Vulnerable to Climate Change? Climate Change Implications on Women with Reference to Food, Water, Energy, Health, and Disaster Security. doi: 10.13140/ RG.2.1.2577.9683/3

Kniveton, D., Visman, E., Tall, A., Diop, M., Ewbank, R., Njoroge, E., \& Pearson, L. (2015). Dealing with uncertainty: Integrating local and scientific knowledge of the climate and weather. Disasters, 39(s1), s35-s53.

Kumar, K. K., Patwardhan, S. K., Kulkarni, A., Kamala, K., Rao, K. K., \& Jones, R. (2011). Simulated projections for summer monsoon climate over India by a high-resolution regional climate model (PRECIS). Current Science, 101(3), 312-326.

Mall, R. K., Singh, R., Gupta, A., Srinivasan, S. G., \& Rathore, L. S. (2006). Impact of climate change in Indian agriculture: A review. Climate Change, 78, 445-478. doi: 10.1007/s10584-005-9042-x

Gezie, M. (2019). Farmer's response to climate change and variability in Ethiopia: A review. Cogent Food \& Agriculture, 5(1), 1613770. doi: 10.1080/23311932.2019.1613770

Meinke, H., Nelson, R., Kokic, P., Stone, R., Selvaraju, R., \& Baethgen, W. (2006). Actionable climate knowledge: From analysis to synthesis. Climate Research, 33(1), 
101-110.

Ministry of Environment and Forest. (2010). Climate Change and India: A $4 \times 4$ Assessment. Retrieved from: http://www.indiaenvironmentportal.org.in/files/ fin-rpt-incca.pdf

Muema, E., Mburu, J., Coulibaly, J., \& Mutune, J. (2018). Determinants of access and utilisation of seasonal climate information services among smallholder farmers in Makueni County, Kenya. Heliyon, 4(11), eoo889.

Opitz-stapleton, S. (2010). Only death is certain, yet you still get out of bed in the morning: Observations on the use of climate information in adaptation and resilience practice. Climate Resilience in Concept and Practice: ISET Working Paper Series. Boulder, Colorado.

Patt, A., Suarez, P., \& Gwata, C. (2005). Effects of seasonal climate forecasts and participatory workshops among subsistence farmers in Zimbabwe. Proceedings of the National Academy of Sciences, 102(35), 12623-12628.

Rengalakshmi, R., Manjula, M., \& Devaraj, M. (2018). Making climate information gender sensitive: Lessons from Tamil Nadu. Economic and Political Weekly LIII, 17, 87-95.

Sathyan, A., Funk, C., Aenis, T., \& Breuer, L. (2018). Climate vulnerability in rainfed farming: Analysis from Indian watersheds. Sustainability, 10(9), 3357. doi: 10.3390/su10093357

Singh, C., Daron, J., Bazaz, A., Ziervogel, G., Spear, D., Krishnaswamy, J., ... \& Kituyi, E. (2018). The utility of weather and climate information for adaptation decision-making: current uses and future prospects in Africa and India. Climate and Development, 10(5), 389-405.

Tall, A., Coulibaly, J. Y., \& Diop, M. (2018). Do climate services make a difference? A review of evaluation methodologies and practices to assess the value of climate information services for farmers: Implications for Africa. Climate Services, 11, 1-12. doi: 10.1016/j.cliser.2018.06.001

UN Women Watch. (2009). Fact sheet: Women, gender equality and climate change. New York.

World Meteorological Organization. (2007). Climate information for adaptation and development needs. WMO-No. 1025. Retrieved from http://www.wmo. int/pages/prog/wcp/cca/documents/WMO_1025_ web_E.pdf

World Meteorological Organization. (2015). WMO prioritizes gender equality. WMO Bulletin, 64(2). Retrieved from https://public.wmo.int/en/resources/bulletin/ wmo-prioritizes-gender-equality

\section{ENDNOTES}

[1] Based on the monsoon pattern in India, the main cropping seasons are divided into Kharif and Rabi: Kharif prevails between June and October coinciding with South-West Monsoon.

[2] Rabi season starts in October and ends in February March in North-East Monsoon season.

[3] See supplementary material. 